\title{
Non-base wage components as a source of wage adaptability to shocks: evidence from European firms, 2010-2013
}

Jan Babecký ${ }^{1}$, Clémence Berson ${ }^{2,3^{*}}$ D, Ludmila Fadejeva ${ }^{4}$, Ana Lamo ${ }^{5}$, Petra Marotzke ${ }^{6}$, Fernando Martins $s^{7,8}$ and Pawel Strzelecki ${ }^{9,10}$

* Correspondence: clemence.berson@banque-france.fr 2Banque de France, Paris, France ${ }^{3}$ University Paris 1, Paris, France Full list of author information is available at the end of the article

\begin{abstract}
This paper provides evidence on the role of non-base wage components as a channel for firms to adjust labour costs in the event of adverse shocks. It uses data from a firm-level survey for 25 European countries that covers the period 2010-2013. We find that firms subject to nominal wage rigidities, which prevent them from adjusting base wages, are more likely to cut non-base wage components when they are hit by negative shocks. Firms thus use non-base wage components as a strategic margin to overcome base wage rigidity. We also show that while non-base wage components exhibit some degree of downward rigidity this is smaller than that observed for base wages.

JEL Classification: J30, J32, C81, P5

Keywords: Downward nominal wage rigidity, Bonuses, Firm survey, European Union
\end{abstract}

\section{Introduction}

Micro-level data on wage variations and survey-based evidence on wage setting have revealed that even in the face of large negative shocks, not only are workers reluctant to accept cuts in their nominal wages, but also firms seem to be unwilling to carry out such cuts. In some countries, these cuts are quite difficult to implement or even forbidden due to labour legislation. This is referred to as downward nominal wage rigidity (DNWR). Besides legal constraints, several reasons have been given in the literature for workers' and employers' resistance to wage cuts. In addition to leading to lower standards of living for workers, such cuts may be considered unfair or demeaning by workers, with subsequent consequences for productivity.

The degree of DNWR determines, among other factors, the speed, nature and cost of adjustment in the presence of economic shocks. However, the relevance of DNWR depends on whether firms have other margins besides base wages to adjust labour costs when needed. Many firms use a combination of different remuneration methods and motivation, so despite the fact that base or bargained wages typically display features of downward rigidity, it is possible that firms are able to vary other forms of remuneration-which may be less important or less visible to

(c) The Author(s). 2019 Open Access This article is distributed under the terms of the Creative Commons Attribution 4.0 International License (http://creativecommons.org/licenses/by/4.0/), which permits unrestricted use, distribution, and reproduction in any medium, provided you give appropriate credit to the original author(s) and the source, provide a link to the Creative Commons license, and indicate if changes were made. 
workers than base wages-to achieve desired adjustments in total labour costs. In many firms, particularly larger ones, performance-related benefits such as bonuses and commissions account for a large and growing share of total compensation. ${ }^{1}$

Even though employees are less likely to oppose changes in these benefits than in their base wages, from the firms' perspective, they are also labour costs. That is why the key point is whether firms can flexibly adjust total compensation as a whole. It could be the case that the effective degree of DNWR turns out to be lower when one accounts for total compensation, leading to a smaller sacrifice ratio and reduced bending of the Phillips curve. There is evidence suggesting that the effects of nominal base wage rigidity are at least partly overcome in this way. Lebow et al. (1999) show that firms are able to mitigate at least a part of the DNWR by changing benefits: total compensation displays about one third less rigidity than do wages alone. Dwyer and Leong (2003) show that broad measures of earnings also display downward rigidity, but to a lesser extent than wages. Bewley (1999), who interviewed the managers of companies in the USA, found that bonuses were frequently used as a way of flexibly reducing expenses when firms were most in need of money. However, he also found that this strategy, similarly to base wage cuts, was connected with some disadvantages: damage to morale and productivity, and increased turnover of better workers.

The decision to extensively use non-base wage components can also be seen as a wage cushion strategy-keeping a difference between contractual and actual wages. In many countries, this strategy (margin) is frequently used to offset collective bargaining, granting firms the possibility of setting wage changes below those negotiated under collective agreements while keeping wages above the bargained floors (Cardoso and Portugal 2005). In Germany, Jung and Schnabel (2011) found evidence that firms bound by multi-firm agreements paid higher wage premiums on average in order to overcome the restrictions imposed by the rather centralised bargaining system.

Based on information from a firm-level survey, Babecký et al. (2012) examine the importance of a variety of strategies that firms may use to cut labour costs, particularly when base wages are rigid. They show that firms subject to DNWR are more likely to use these strategies, suggesting the presence of some degree of substitutability between base wage and non-base wages. Dias et al. (2013) provide evidence that in the face of negative shocks, the availability of alternative labour cost margins is likely to reduce the detrimental effect on employment that results from the presence of DNWR. There is also evidence that non-base wage components were frequently adjusted during the first period of the economic crisis in 2008-2009 (see European Central Bank 2009 and Fabiani et al. 2015).

In this paper, we examine the role of non-base wage components as a channel of labour cost adjustment in firms facing adverse economic shocks during 2010-2013. We analyse the relationship between wage rigidities and the use of non-base wage component adjustment and the different responses of base wages and non-base wages to shocks. ${ }^{2}$

We use a unique dataset based on a survey of firms from 25 European Union countries undertaken between the end of 2014 and mid-2015 as part of the third wave of the Wage Dynamics Network-a Eurosystem research network created in 2006 and reactivated in 2013 with the main purpose of assessing labour market adjustments in the period 2010-2013. 
Results reveal that bonuses and other performance-related benefits (non-base wage components) were an important adjustment mechanism for firms in the period 20102013. About $75 \%$ of the firms used this margin to reduce labour costs in 2013. The reported average share of non-base wage components is $7 \%$, which is somewhat lower than the figure obtained for 2007 in the context of a similar survey. The percentage of firms that cut non-base wage components during 2010-2013 (13\%) is larger than the percentage that cut base wages (5\%).

The results also indicate that non-base wage components played a role as shock absorbers during the period 2010-2013. Under DNWR, firms are more likely to cut non-base wages in order to adjust labour costs. Shocks are associated with an increased reduction of non-base wage components. While firms hit by negative demand shocks are more likely to reduce both base wages and non-base wage components, the increase in the probability of reducing non-base wages is higher than that of reducing base wages. This is also found for other negative shocks.

The rest of the paper is structured as follows. Section 2 briefly describes the data and the main stylised facts; Section 3 examines first the relationship between non-base wage component adjustment and (base) wage rigidities and then looks in detail at base wage and non-base wage component adjustment in the presence of various combinations of shocks. The last section concludes.

\section{Data and stylised facts}

\subsection{The WDN3 survey}

The data used in this paper were collected in the third wave of the Wage Dynamics Network survey (WDN3) coordinated by the European Central Bank. ${ }^{3}$ The survey was carried out between 2014 and the beginning of 2015 by 25 EU national central banks ${ }^{4}$ based on a harmonised questionnaire referring to the period 2010-2013 (see Izquierdo et al. (2017) for the summary of WDN3 cross-country results). The WDN3 survey provided a unique cross-country dataset of labour market adjustment practices and wage and price setting mechanisms of firms with exceptional value in terms of both geographical and sectoral coverage. The data allow recent labour market adjustments to different shocks, such as change in demand, customers' ability to pay and credit availability, to be assessed.

Although the national surveys were organised and carried out by each national central bank separately, the questionnaire and the target population of firms were very similar across countries. A "core questionnaire" was developed in a coordinated fashion within the WDN. To further harmonise the findings across countries, we restrict our sample to firms employing more than five employees and operating in manufacturing, electricity and gas, construction and services (trade, market services and financial intermediation).

In the WDN3 survey, firms were asked questions pertaining to the different margins of labour cost adjustment, including a reduction of employees, both permanent and temporary; base wage freezes; changes in the non-base wage components and cuts in the number of hours worked. Using these answers together with information on firms' size, sector, institutional background and shocks gives us an opportunity to assess the effect of shocks on labour cost adjustment. 
To explore the structure of firm labour costs, i.e. the share of non-base wage components of a firm, firms were asked to report the share of individual or company performance-related bonuses and benefits in the total wage bill in 2013. We use this self-reported ratio as a measure of non-base wage in total pay of the firm.

As regards the components of labour costs, firms were asked the following question: "Please indicate how each one of the components of labour costs listed below has changed during 2010-2013. Please choose ONE option for each line." The list included the following options:

1) Base wages or piece work rates

2) Non-base wage components (bonuses, fringe benefits etc.)

3) Number of permanent employees

4) Number of temporary/fixed-term employees

5) Working hours per employee

6) Other components (please specify)

Firms participating in the survey were required to report for each option listed above whether they observed (a) strong decrease, (b) moderate decrease, (c) unchanged, (d) moderate increase or (e) strong increase. In the analysis below, we classify a firm as having cut the corresponding component of labour costs if the answer was strong or moderate decrease.

The survey also provides relevant information on the nature of the shocks faced by firms during the period 2010-2013. For the purposes of this paper, we consider shocks to:

i) Level of demand for products/services

ii) Access to external financing through the usual financial channels

iii) Customers' ability to pay and meet contractual terms

Firms were required to report for each option whether they observed (a) strong decrease, (b) moderate decrease, (c) no change, (d) moderate increase or (e) strong increase. We use this question to identify how firms were affected by different shocks. For instance, we use changes in the level of demand (both moderate and strong) to identify firms that were hit by demand shocks and changes in access to external financing (both moderate and strong) to detect firms that were hit by credit shocks. Of course, these shocks could be positive if firms reported an increase, negative if firms reported a decrease or non-existent if firms reported no change in activity.

We use a question on the use of base wage freezes in the given year (a yes/no answer) to construct the DNWR measure at the firm level. We regard firms that froze base wages during 2010-2013 as confronting DNWR.

\subsection{Stylised facts}

About $74 \%$ of the firms covered in our sample paid bonuses and other performance-related benefits (non-base wage components) in 2013 (see Table 1). ${ }^{5}$ 
Table 1 Non-base wage components by firm size and sector in 2013

\begin{tabular}{llll}
\hline & $\begin{array}{l}\text { Firms using non-base } \\
\text { wage components (\%) }\end{array}$ & $\begin{array}{l}\text { Non-base wage in total } \\
\text { pay, unconditional (\%) }\end{array}$ & $\begin{array}{l}\text { Non-base wage in total } \\
\text { pay, conditional (\%) }\end{array}$ \\
\hline Size & & & 12.4 \\
5-19 employees & 54.9 & 6.8 & 9.5 \\
20-49 employees & 64.1 & 6.1 & 8.5 \\
50-199 employees & 73.7 & 6.3 & 9.1 \\
> 200 employees & 84.9 & 7.7 & \\
Sector & & & 8.4 \\
Manufacturing & 75.9 & 6.4 & 10.0 \\
Electricity, gas, water & 82.9 & 8.3 & 10.1 \\
Construction & 59.8 & 6.0 & 10.8 \\
Trade & 75.0 & 8.1 & 8.6 \\
Business services & 73.6 & 6.3 & 16.0 \\
Financial intermediation & 92.7 & 14.9 & 11.3 \\
Non-euro area & 74.9 & 8.5 & 8.3 \\
Euro area & 73.6 & 6.1 & 7.9 \\
Collective agreement & 74.4 & 5.9 & 11.0 \\
No collective agreement & 74.0 & 8.2 & 9.3 \\
Wage index. on inflation & 76.5 & 7.1 & 9.6 \\
No wage indexation & 74.3 & 7.1 & 9.3 \\
Total & 74.2 & 6.9 & \\
\hline
\end{tabular}

WDN3, authors' calculation. The data are weighted to reflect overall employment and rescaled to exclude non-response. Statistics on wage indexation do not include Ireland and the Netherlands

There is some cross-country heterogeneity, ranging from more than $90 \%$ of firms in Slovakia and Portugal to less than $55 \%$ in Luxembourg, Ireland and Cyprus (Additional file 1: Table S1).

The average share of non-base wage components in the total wage bill in 2013 was around $7 \%$ when calculated by averaging over all the firms sampled and $9.5 \%$ when calculated only across companies that pay non-base wages. Underlying this average, there is large cross-country heterogeneity. While the share of non-base wage components in the total bill in 2013 is $25 \%$ on average in Portugal, it is about $4 \%$ in Luxembourg and Ireland. When compared with the pre-crisis period, the average share of non-base wage components in the total wage bill of the firms sampled in 2007 was $11.3 \%$, falling to $7.4 \%$ in 2013 for the subset of countries that participated in the WDN1 survey and $6.9 \%$ for the 25 WDN3 countries $^{6}$ (see Additional file 1: Table S1). The smaller fraction of non-base wage components in the total wage bill in 2013 may reflect the slower economic growth in 2013 relative to the pre-crisis period (2002-2007), but it is also suggestive of an increased role of non-base wage cuts as a means of adjusting the wage bill during the crisis, in line with the higher share of companies paying bonuses and other performance-related benefits in 2013 (75\%) compared to 2007 (72\%).

Larger firms are more likely to use non-base wage components (85\% of firms with more than 200 employees vs. 55\% of firms with 5-19 employees; see Table 1). The smaller firms using non-base wages, on the other hand, dedicate a larger share of total pay to this wage component (12\%, compared to about $9 \%$ in firms of other sizes). The use of non-base wage components is also quite sector-specific. More than $92 \%$ of firms 
in financial intermediation sector use it and pay higher non-base wage shares compared to other sectors. At the other extreme, only $60 \%$ of firms in the construction sector pay a part of their wages as non-base wage components. Firms of the euro area pay lower non-base wage shares than those out of the euro area even if the share of firms using non-base wages is similar. Concerning wage setting, firms pay lower non-base wages when a collective agreement is in effect in the firm. However, wage indexation on inflation plays no role.

To understand the role that non-base wages played as a means of adjusting labour costs, we cannot ignore the incidence of different adverse shocks faced by firms during 2010-2013. The WDN results show that the share of firms affected by different shocks varies largely depending on the country and the nature of shock (Fig. 1). As expected, countries that were more affected by the sovereign debt crisis (Greece, Spain, Portugal and Italy) are also those where a larger share of firms reported facing negative shocks during 2010-2013. Importantly, firms in 14 out of the 25 countries viewed a decline in customers' ability to pay as more severe than a decline in demand, though the two shocks are very much related. Unavailability of external finance (a credit constraint shock) was faced by a smaller share of firms in all countries.

Combining the information on negative economic shocks perceived by firms with that on changes in non-base wage components provides some hints on whether firms use non-base wage components as a shock absorber (see Table 2). The percentage of firms having cut non-base wages was larger in countries in which the percentage of firms experiencing either a strong or a moderate decline in any of the observed shocks was also larger. In the majority of countries, stronger negative shocks implied that more firms reduced non-base wage components.

Table 3 presents the percentage of firms adjusting non-base wages by sector and firm size. The percentage of firms that cut non-base wage components is larger in financial intermediation, in line with the larger prevalence of non-base wage components in this sector (see Table 1). This share is lower in other sectors, particularly the electricity and gas sector. The shares of firms having cut non-base wage components by firm size are more even. However, large firms more often use reductions in non-base wage

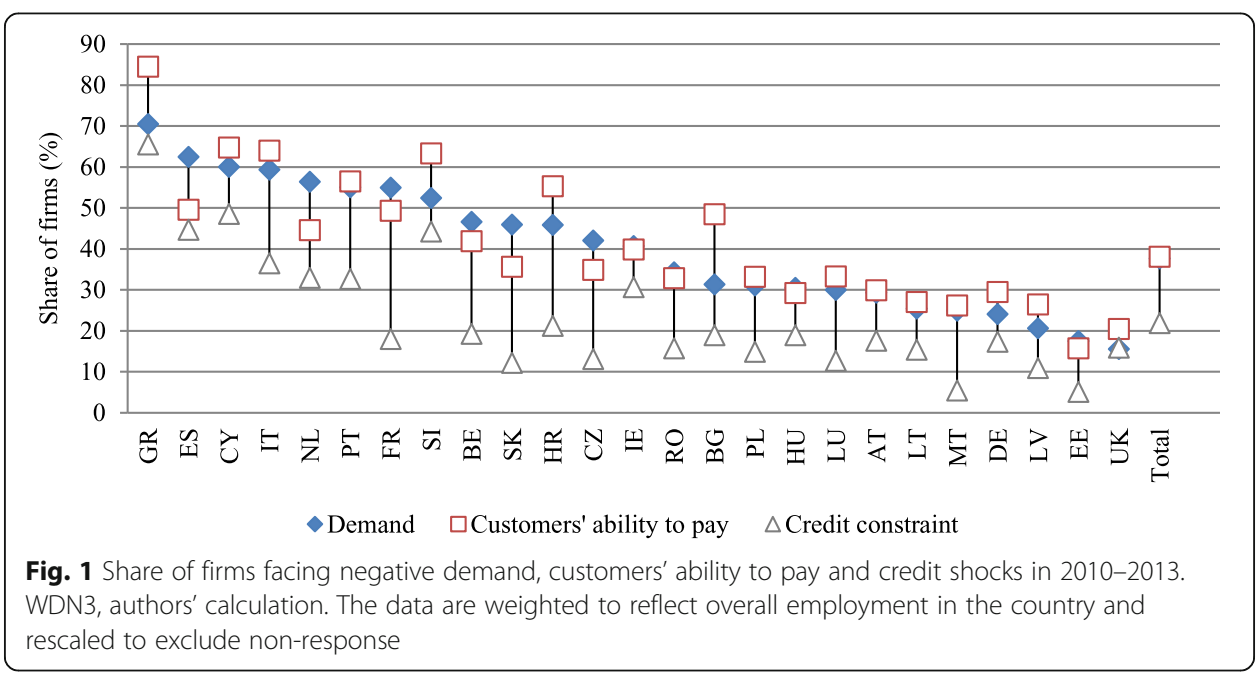


Table 2 Percentage of firms having cut non-base wage components in 2010-2013 by country

\begin{tabular}{|c|c|c|c|c|}
\hline \multirow[t]{2}{*}{ Country } & \multirow[t]{2}{*}{ Unconditional } & \multicolumn{3}{|l|}{ Conditional on having faced } \\
\hline & & $\begin{array}{l}\text { Negative shocks (either strong or } \\
\text { moderate) }\end{array}$ & $\begin{array}{l}\text { At least one strong } \\
\text { negative shock }\end{array}$ & $\begin{array}{l}\text { Only strong negative } \\
\text { shocks }\end{array}$ \\
\hline AT & 6.1 & 6.1 & 9.0 & \\
\hline BE & 2.8 & 2.9 & 3.1 & \\
\hline BG & 21.1 & 34.1 & 42.9 & 44.1 \\
\hline CY & 52.2 & 63.4 & 64.7 & 52.4 \\
\hline$C Z$ & 21.6 & 32.1 & 43.7 & 70.4 \\
\hline $\mathrm{DE}$ & 4.3 & 6.7 & 14.6 & 58.9 \\
\hline $\mathrm{EE}$ & 5.8 & 18.5 & 40.3 & \\
\hline ES & 23.7 & 28.4 & 22.3 & 26.7 \\
\hline FR & 12.1 & 13.8 & 17.9 & 35.7 \\
\hline GR & 50.9 & 53.8 & 59.2 & 72.7 \\
\hline $\mathrm{HR}$ & 24.2 & 33.4 & 42.3 & 86.4 \\
\hline $\mathrm{HU}$ & 20.0 & 28.5 & 33.1 & 51.7 \\
\hline IE & 27.7 & 39.4 & 49.3 & 58.6 \\
\hline IT & 19.9 & 22.4 & 28.4 & 53.0 \\
\hline LT & 11.2 & 19.0 & 35.1 & 74.5 \\
\hline LU & 15.5 & 23.5 & 29.7 & \\
\hline LV & 10.6 & 24.0 & 45.5 & 26.7 \\
\hline MT & 0.4 & 1.0 & 5.6 & \\
\hline $\mathrm{NL}$ & 28.1 & 35.5 & 37.4 & 48.3 \\
\hline$P L$ & 11.8 & 11.6 & 24.0 & 16.5 \\
\hline PT & 21.7 & 25.3 & 30.2 & 40.3 \\
\hline RO & 11.2 & 20.6 & 30.1 & 49.0 \\
\hline SI & 30.4 & 35.1 & 44.5 & 61.9 \\
\hline SK & 17.4 & 20.6 & 23.9 & 46.2 \\
\hline UK & 9.3 & 14.9 & 14.7 & \\
\hline Total & 13.0 & 18.2 & 25.0 & 41.4 \\
\hline
\end{tabular}

WDN3, authors' calculation. The shocks considered are change in demand, customers' ability to pay and access to external finance. The data are weighted to reflect overall employment in the country and rescaled to exclude non-response

components as shock absorbers. Firms facing negative shock use reductions of non-base wage components more frequently in all sectors and firm size categories, whatever the wage setting characteristics and the belonging to the euro area.

The adjustment of non-base wage components is not the only labour cost adjustment channel potentially used by firms in response to negative shocks. In fact, previous studies find that firms use several adjustment channels simultaneously when reducing labour costs (Messina et al. 2010). Table 4 presents the sample conditional proportions of several adjustment margins, such as base and non-base wage components, hours and employment, both for all firms in the sample and for those firms that were affected by negative shocks in the three dimensions considered (demand, customers' ability to pay and access to external financing).

Regardless of the strength of the shocks, the proportion of firms that cut the number of employees is larger than the proportion of firms that cut hours or wages. A larger share of firms report base wage freezes compared to cuts in either base or non-base 
Table 3 Percentage of firms having cut non-base wage components in 2010-2013 by sector and size

\begin{tabular}{|c|c|c|c|c|}
\hline & \multirow[t]{2}{*}{ Unconditional } & \multicolumn{3}{|l|}{ Conditional on having faced } \\
\hline & & $\begin{array}{l}\text { Negative shocks (either strong } \\
\text { or moderate) }\end{array}$ & $\begin{array}{l}\text { At least one strong } \\
\text { negative shock }\end{array}$ & $\begin{array}{l}\text { Only strong } \\
\text { negative shocks }\end{array}$ \\
\hline \multicolumn{5}{|l|}{ Sector } \\
\hline Manufacturing & 10.7 & 16.1 & 24.0 & 40.1 \\
\hline Electricity, gas & 3.6 & 6.6 & 29.5 & \\
\hline Construction & 15.0 & 20.0 & 28.2 & 43.8 \\
\hline Trade & 14.8 & 20.5 & 23.6 & 41.2 \\
\hline Business service & 13.3 & 17.6 & 25.0 & 40.3 \\
\hline $\begin{array}{l}\text { Financial } \\
\text { intermediation }\end{array}$ & 18.2 & 31.4 & 37.8 & 64.6 \\
\hline \multicolumn{5}{|l|}{ Size } \\
\hline 5-19 employees & 12.7 & 16.3 & 22.9 & 39.6 \\
\hline $\begin{array}{l}\text { 20-49 } \\
\text { employees }\end{array}$ & 11.9 & 16.7 & 25.7 & 38.6 \\
\hline $\begin{array}{l}\text { 50-199 } \\
\text { employees }\end{array}$ & 12.0 & 16.6 & 23.6 & 36.5 \\
\hline $\begin{array}{l}>200 \\
\text { employees }\end{array}$ & 14.1 & 20.7 & 27.1 & 48.5 \\
\hline Non-euro area & 12.3 & 26.1 & 33.4 & 39.3 \\
\hline Euro area & 13.4 & 22.2 & 30.5 & 35.2 \\
\hline $\begin{array}{l}\text { Collective } \\
\text { agreement }\end{array}$ & 14.4 & 23.1 & 30.6 & 33.6 \\
\hline $\begin{array}{l}\text { No collective } \\
\text { agreement }\end{array}$ & 11.2 & 22.1 & 30.0 & 39.0 \\
\hline $\begin{array}{l}\text { Wage index. on } \\
\text { inflation }\end{array}$ & 10.8 & 19.4 & 28.6 & 29.7 \\
\hline $\begin{array}{l}\text { No wage } \\
\text { indexation }\end{array}$ & 13.2 & 22.5 & 30.7 & 33.6 \\
\hline Total & 13.0 & 18.2 & 25.0 & 41.4 \\
\hline
\end{tabular}

WDN3, authors' calculation. As in Table 2

wage components. However, in the subsample of firms facing only strong negative shocks, the share of firms using base wage freezes or non-base wage cuts is similar.

In every country in our sample except Greece and, to a lesser extent, Cyprus (Additional file 1: Table S2), the proportion of firms that cut non-base wage components during 2010-2013 is larger than the proportion that cut base wages. This is not surprising and points to possible substitution between the two adjustment channels, in line with the findings of Babecký et al. (2012), Lebow et al. (1999) and Bewley (1999), among others. Substitution between base and non-base wages is particularly relevant for firms in France, Portugal, Luxembourg and Spain, where it is harder to reduce base wages for permanent employment. In the Baltic countries (Estonia, Latvia and Lithuania) and Poland and Croatia, firms are more flexible in the choice of adjustment margin due to generally lower base wage rigidity. ${ }^{7}$

Table 4 shows the proportions of firms using some labour cost-cutting margin both for all firms in the sample and for those firms that were negatively affected by shocks. As expected, the proportion of firms using any labour cost-cutting margin increases within the sample of firms that were negatively affected by at least one shock. For 
Table 4 Sample conditional proportions of negative change in labour cost margins in 2010-2013 (proportions calculated as weighted relative frequencies)

\begin{tabular}{|c|c|c|c|c|c|}
\hline & $\begin{array}{l}\text { Cut base } \\
\text { wages }\end{array}$ & $\begin{array}{l}\text { Cut non-base } \\
\text { wages }\end{array}$ & $\begin{array}{l}\text { Cut number of } \\
\text { employees }\end{array}$ & $\begin{array}{l}\text { Cut number of } \\
\text { hours }\end{array}$ & $\begin{array}{l}\text { Freeze base } \\
\text { wages }\end{array}$ \\
\hline$P()$. & 0.053 & 0.130 & 0.329 & 0.114 & 0.262 \\
\hline \multicolumn{6}{|c|}{ Having faced negative shocks (either strong or moderate) } \\
\hline$P()$. & 0.075 & 0.182 & 0.423 & 0.162 & 0.296 \\
\hline P (.|cut non-base wages) & 0.260 & 1.000 & 0.745 & 0.270 & 0.471 \\
\hline P (.|cut base wages) & 1.000 & 0.631 & 0.784 & 0.293 & 0.508 \\
\hline P (.|cut non-base and base wages) & 1.000 & 1.000 & 0.862 & 0.331 & 0.580 \\
\hline \multicolumn{6}{|c|}{ Having faced at least one strong negative shock } \\
\hline $\mathrm{P}()$. & 0.108 & 0.250 & 0.552 & 0.226 & 0.365 \\
\hline P (.|cut non-base wages) & 0.319 & 1.000 & 0.783 & 0.313 & 0.491 \\
\hline P (.|cut base wages) & 1.000 & 0.739 & 0.854 & 0.352 & 0.548 \\
\hline P (.|cut non-base and base wages) & 1.000 & 1.000 & 0.879 & 0.389 & 0.604 \\
\hline \multicolumn{6}{|c|}{ Having faced only strong negative shocks } \\
\hline$P()$. & 0.209 & 0.414 & 0.704 & 0.302 & 0.449 \\
\hline P (.|cut non-base wages) & 0.441 & 1.000 & 0.819 & 0.337 & 0.529 \\
\hline P (.|cut base wages) & 1.000 & 0.875 & 0.893 & 0.426 & 0.559 \\
\hline P (.|cut non-base and base wages) & 1.000 & 1.000 & 0.905 & 0.455 & 0.542 \\
\hline
\end{tabular}

WDN3, authors' calculation. The shocks considered are change in demand, customers' ability to pay and access to external finance. The measure of change in a firm's (internal) number of employees combines permanent and temporary employees. The results are weighted to reflect overall employment in the country and rescaled to exclude non-response

instance, the share of firms that cut the number of employees, either permanent or temporary, increases from $33 \%$ in the whole sample to $42 \%$ in the sample of firms facing shocks. Perhaps more interesting is that the proportion of firms cutting employment reaches $75 \%$ among firms that also cut non-base wages, $78 \%$ among those that also cut their base wages and $86 \%$ for those that cut both. These percentages are even higher if any of the shocks was deemed to be strong. This suggests that firms tend to use several available cost-cutting margins, the more so the more strongly they are hit by the crisis.

Lastly, Fig. 2 presents the share of firms freezing base wages during 2010-2013. This ranking is mainly in line with the share of countries experiencing negative shocks (Fig. 1), which points to the prevalence of DNWR that prevents these firms suffering shocks from

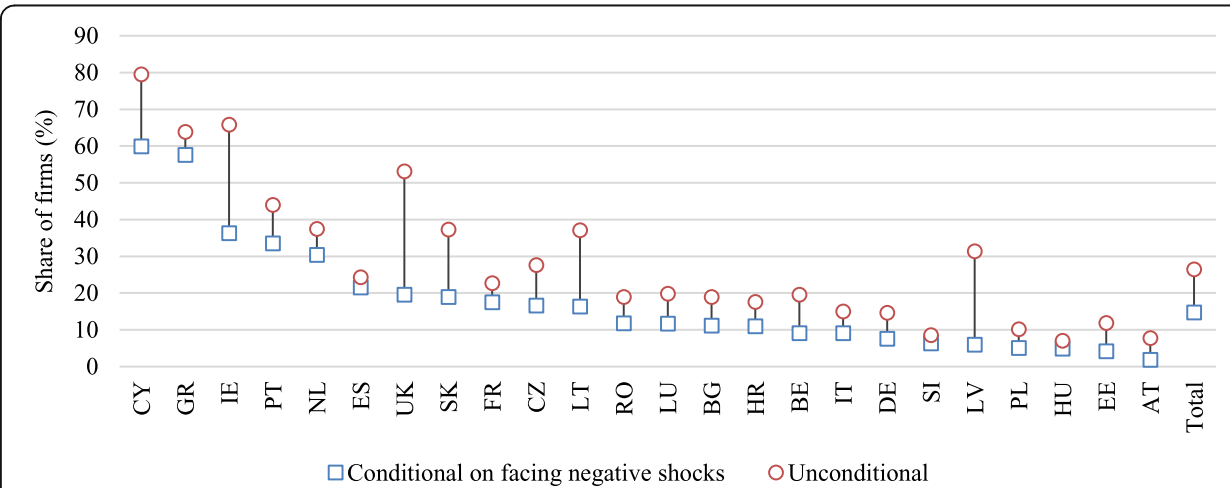

Fig. 2 Share of firms freezing wages in 2010-2013,\%. WDN3, authors' calculation. The data are weighted to reflect overall employment in the country and rescaled to exclude non-response 
cutting base wages, having to freeze instead. The exception is the UK and Ireland-where a large share of firms report wage freezes despite a lower level of firms facing negative shocks on average. In these countries, along with Cyprus, Slovakia, Lithuania and Latvia, firms used the opportunity to reduce labour costs by exploiting the low overall level of economic sentiment without actually facing negative shocks at the time.

\section{Results}

\subsection{Do firms use non-base wage components as a buffer to overcome base wage} rigidity?

In this section, we provide a first-glance examination of the relationship between non-base component adjustment and base wage rigidity. For that purpose, we explore whether those firms subject to nominal base wage rigidity are more or less likely to respond to shocks cutting the non-base component of wages.

To construct a measure of DNWR, we use the information contained in the WDN3 survey about base wage freezes. The survey asked managers of firms directly if they ever froze wages during the period 2010-2013. Wage freezes indicate that base wage cuts were prevented from taking place due to DNWR, and more so in a downturn, when economic conditions are likely to necessitate a cut in base wages. Then, following Dickens et al. (2007) and Dias et al. (2015) (see also Nickell and Quintini 2003), we regard firms that froze wages at any point during this period as facing nominal base wage rigidity. We assume that in those firms, everyone whose base wages were frozen would have had a nominal wage cut in the absence of DNWR. ${ }^{8}$

In order to identify the potential determinants of the probability of cutting non-base wage components and in particular its relationship with DNWR, we consider a number of firm characteristics, such as size or skill distribution, collective bargaining, bargaining coverage and labour cost share, together with our measure of DNWR, and control for the various types of shocks explained in the stylised facts section. The result of the probit estimations is summarised in Table 5, where the dependent variable takes the value of 1 if the firm cut non-base wage components over the period 2010-2013. ${ }^{9}$ We find that firms subject to nominal rigidity are more likely to cut non-base wage components, in line with the larger share of firms reducing various labour cost margins in the presence of DNWR (Additional file 1: Table S2). This result is robust to the choice of other control variables, including the type of shocks and the interaction terms between shocks and nominal wage rigidity (Table 5, column 3 ). Interestingly, while non-base wage cuts are correlated with shocks and with freezes of base wages, the effects do not stem from the interactions. ${ }^{10}$

Regarding other determinants influencing the decision to adjust non-base wage components, it turns out that, as suggested by the descriptive analysis in Section 2, larger firms are more likely to use non-base wage components (Additional file 1: Table S3). Similarly, firms with a higher labour cost share and a higher share of tenured workers, as well as firms in construction and financial intermediation, are more likely to adjust non-base wage components than firms in manufacturing.

Next, we explore the effect of unions on firms' use of non-base wage components. Additional file 1: Table S4 shows that unionisation and the type of wage bargaining have no significant effects. Moreover, different combinations and interactions of 
Table 5 Relationship between cuts in non-base wage components and base wage rigidity

\begin{tabular}{|c|c|c|c|}
\hline & (1) & (2) & (3) \\
\hline \multicolumn{4}{|l|}{ Base wage rigidity } \\
\hline \multirow[t]{2}{*}{ DNWR base wage freezes } & $0.117^{* * *}$ & $0.086^{* * *}$ & $0.084^{* * *}$ \\
\hline & $(0.010)$ & $(0.008)$ & $(0.016)$ \\
\hline \multicolumn{4}{|l|}{ Shocks } \\
\hline \multirow[t]{2}{*}{ Demand shock } & & $0.109^{* * *}$ & $0.114^{* * *}$ \\
\hline & & $(0.013)$ & $(0.015)$ \\
\hline \multirow[t]{2}{*}{ Finance shock } & & $0.058^{* * *}$ & $0.062^{* * *}$ \\
\hline & & $(0.007)$ & $(0.008)$ \\
\hline \multirow[t]{2}{*}{ Customers' ability to pay shock } & & $0.032^{* * *}$ & $0.019^{* *}$ \\
\hline & & $(0.008)$ & $(0.009)$ \\
\hline \multirow[t]{2}{*}{ Availability of supplies shock } & & $0.028^{* * *}$ & $0.033^{* * *}$ \\
\hline & & $(0.006)$ & $(0.008)$ \\
\hline \multicolumn{4}{|l|}{ DNWR * shocks } \\
\hline \multirow[t]{2}{*}{ Base wage freezes and demand shock } & & & -0.019 \\
\hline & & & $(0.021)$ \\
\hline \multirow[t]{2}{*}{ Base wage freezes and customer pay shock } & & & $0.038^{* * *}$ \\
\hline & & & $(0.012)$ \\
\hline \multirow[t]{2}{*}{ Base wage freezes and credit shock } & & & -0.014 \\
\hline & & & $(0.013)$ \\
\hline \multirow[t]{2}{*}{ Base wage freezes and availability of supplies shock } & & & $-0.015^{*}$ \\
\hline & & & $(0.009)$ \\
\hline Observations & 19,234 & 18,582 & 18,582 \\
\hline
\end{tabular}

Marginal effects reported. Probit estimation. The dependent variable is equal to one if the firm reduces non-base wage components. Standard errors in parentheses. The estimation is controlled for sectors, firm size, labour cost share, share of manual workers, workers' tenure, multi-establishments and country fixed effects. See Additional file 1: Table S3 for the full set of results

${ }^{* * *} p<0.01,{ }^{* *} p<0.05,{ }^{*} p<0.1$

variables, sectors and collective bargaining characteristics are not significant and do not affect the main results. Thus, substitutability between base and non-base wages to overcome DNWR is not limited by the presence of unions. In fact, collective wage bargaining and coverage do not appear relevant as regards the decision to cut non-base wage components. In addition, the higher likelihood of adjusting non-base wage components when DNWR is prevalent persists no matter what type of shocks the firm is facing (see Additional file 1: Table S4).

To sum up, at the margin, firms affected by DNWR are more likely to reduce non-base wage components than those not showing base wage rigidities. Hence, there is evidence of non-base wages being used as a buffer to overcome base wage rigidity.

However, firms combine several adjustment channels when needed. The next section explores the relationship between base and non-base wage component adjustments more generally and compares their degree of downward rigidity.

\subsection{Adjustment of base wages and non-base wage components to shocks}

In order to explore the relation between the adjustment of base wages and non-base wage components, we start by reporting the frequencies of different base wage and 
non-base wage reactions to changing economic conditions. Then, we estimate their probabilities.

\subsubsection{Incidence of base wage and non-base wage component reductions}

We consider four possible combinations of base and non-base wage adjustment by firms in response to negative shocks:

1. Reduce neither base nor non-base wage components (base $=0$, flex $=0$ )

2. Reduce only non-base wage components (base $=0$, flex $=1$ )

3. Reduce both base and non-base wage components (base $=1$, flex $=1$ )

4. Reduce only base wages (base $=1$, flex $=0$ )

We find that firms are reluctant to reduce wages and mostly choose the first option (Table 6). This is also the case when we consider various subsamples of firms which are hit by a fall in demand, a fall in demand or customers' ability to pay, and additionally a fall in credit access. For all groups considered, the second most frequent option is to reduce solely the non-base wage component. It is chosen approximately three times more often than the joint reduction of base wages and non-base wage components. Base wage reductions without reducing non-base wage components are rare.

The option not to reduce wages is chosen by $83.6 \%$ of all firms. The fraction is lower for firms which experience a fall in demand (73.3\%). The fraction of firms which reduce non-base wage components only or which additionally reduce base wages increases substantially from 10.9 to $18.0 \%$ and from 3.5 to $6.0 \%$. The fraction of firms which reduce base wages alone rises only from 2.0 to $2.8 \%$. The evidence suggests that non-base wage components are more reactive in the case of negative shocks.

\subsubsection{Response of base wages and non-base wage components to changes in demand}

In order to compare the likelihood and determinants of changes in base and non-base wage components, we estimate ordered probit models, related through the error terms (seemingly unrelated regressions (SUR)). The underlying latent variable models are as follows:

$$
\begin{aligned}
& \text { base }=X \beta_{b}+u_{b} \\
& \text { flex }=X \beta_{f}+u_{f}
\end{aligned}
$$

\begin{tabular}{|c|c|c|c|c|c|c|}
\hline & \multicolumn{4}{|c|}{ Wage adjustment options (\%) } & \multirow{4}{*}{ Total } & \multirow{4}{*}{ Obs. } \\
\hline & \multirow{3}{*}{$\begin{array}{l}(1) \\
\text { base }=0 \\
\text { flex }=0\end{array}$} & \multirow{3}{*}{$\begin{array}{l}(2) \\
\text { base }=0 \\
\text { flex }=1\end{array}$} & \multirow{3}{*}{$\begin{array}{l}(3) \\
\text { base }=1 \\
\text { flex }=1\end{array}$} & \multirow{3}{*}{$\begin{array}{l}(4) \\
\text { base }=1 \\
\text { flex }=0\end{array}$} & & \\
\hline & & & & & & \\
\hline Subsample of firms & & & & & & \\
\hline Total & 83.6 & 10.9 & 3.5 & 2.0 & 100 & 19,855 \\
\hline Decline in demand & 73.3 & 18.0 & 6.0 & 2.8 & 100 & 8828 \\
\hline Decline in demand or in customers' ability to pay & 77.1 & 15.1 & 5.0 & 2.8 & 100 & 11,814 \\
\hline $\begin{array}{l}\text { Decline in demand or in customers' ability to } \\
\text { pay and credit restrictions }\end{array}$ & 76.5 & 15.4 & 5.4 & 2.6 & 100 & 9494 \\
\hline
\end{tabular}

Table 6 Incidence of wage reductions

WDN3, authors' calculation. The data are weighted to reflect overall employment. Estimation sample of Section 3.2.2 
where base and flex reflect the adjustment of base and non-base wages respectively (decrease, unchanged, increase), $X$ are the firm's characteristics and $u_{b}$ and $u_{f}$ are the related error terms. The firms' characteristics include its structure, ownership, size, country and sector as well as the change in economic conditions.

We find that firms which are hit by negative demand shocks are more likely to reduce base wages and non-base wage components compared to the reference category of unchanged demand (Table 7). However, the increase in the likelihood of wage reduction is stronger for non-base wage components than for the base wage. When facing positive demand shocks, firms increase both base wage and non-base wage components and they do so to the same extent, or, to be more precise, the increase in the likelihood is not significantly different. We find a stronger upward response of wages to an increase in demand than a downward response to a fall in demand for both base wages and non-base wage components. Further, a fall in demand significantly increases the probability that wages remain unchanged, while an increase in demand lowers the probability of unchanged wages. This asymmetry is evidence of downward rigidity (see Marotzke et al. 2017). The effect of a fall in demand on unchanged wages is larger for base wages than for non-base wage components. We conclude from the comparison of marginal effects that downward rigidity is stronger for base wages than for non-base wage components. ${ }^{11}$

\subsubsection{Effect of various types of negative shocks}

Next, we explore the effect of various types of negative shocks on wage adjustment. We include the strength and persistency of the demand shock, which gives us four different categories of negative demand changes.The results in Table 8 show that all categories of the fall in demand exhibit consistent effects. Firms which are hit by a negative demand shock are more likely to reduce both base wages and non-base wage components. A strong fall in demand induces a stronger marginal effect than a moderate fall in demand. The largest marginal effect is in response to a strong, long-lasting negative demand shock. The strength and persistence of a fall in demand does not affect the marginal effect of a fall in demand on the probability of unchanged non-base wages. However, the marginal effect of a fall in demand on the probability of base wages remaining unchanged is higher when the shock is strong, which might reflect stronger downward rigidity of base wages. We find that the marginal effect on the probability of reducing non-base wages is stronger than in the case of base wages (see the first column in Table 8).

The other negative shocks (finance, customers and supplies) exhibit very consistent negative effects on wages. Non-base wage components react more strongly than base wages to negative shocks. Further, the marginal effect of all types of negative shocks on the probability of keeping base wages unchanged is larger than that on the probability of base wages being reduced, while it is the other way around for non-base wage components. This means that firms find it easier to reduce non-base wage components.

\section{Conclusion}

Bonuses and other performance-related benefits declined considerably during 2010-2013 in comparison with the pre-crisis period. The average share of performance-related benefits in the total wage bill of the firms sampled in 2007 was $11.3 \%$. The figure fell to $7.4 \%$ in 2013 for the subset of countries that participated in the first WDN survey, while for the 
Table 7 Base wage and non-base wage adjustment, SUR estimates

\begin{tabular}{|c|c|c|c|}
\hline & (1) & (2) & (3) \\
\hline & Base wages & Base wages & Base wages \\
\hline & Decrease & Unchanged & Increase \\
\hline \multicolumn{4}{|l|}{ Demand } \\
\hline \multirow[t]{2}{*}{ Decrease } & $0.027^{* * *}$ & $0.040^{* * *}$ & $-0.067^{* * *}$ \\
\hline & $(0.003)$ & $(0.005)$ & $(0.008)$ \\
\hline Unchanged (reference) & - & - & - \\
\hline \multirow[t]{2}{*}{ Increase } & $-0.040^{* * *}$ & $-0.095^{* * *}$ & $0.135^{* * *}$ \\
\hline & $(0.003)$ & $(0.006)$ & $(0.008)$ \\
\hline \multirow[t]{2}{*}{ Finance shock } & $0.023^{* * *}$ & $0.036^{* * *}$ & $-0.059^{* * *}$ \\
\hline & $(0.003)$ & $(0.004)$ & $(0.008)$ \\
\hline \multirow[t]{2}{*}{ Customers' ability to pay shock } & $0.007^{* *}$ & $0.011^{* *}$ & $-0.017^{* *}$ \\
\hline & $(0.003)$ & $(0.004)$ & $(0.007)$ \\
\hline \multirow[t]{4}{*}{ Availability of supplies shock } & $0.010^{* * *}$ & $0.015^{* * *}$ & $-0.024^{* * *}$ \\
\hline & $(0.003)$ & $(0.005)$ & $(0.008)$ \\
\hline & Non-base wages & Non-base wages & Non-base wages \\
\hline & Decrease & Unchanged & Increase \\
\hline \multicolumn{4}{|l|}{ Demand } \\
\hline \multirow[t]{2}{*}{ Decrease } & $0.070^{* * *}$ & $0.021^{* * *}$ & $-0.091^{* * *}$ \\
\hline & $(0.005)$ & $(0.002)$ & $(0.007)$ \\
\hline Unchanged (reference) & - & - & - \\
\hline \multirow[t]{2}{*}{ Increase } & $-0.064^{* * *}$ & $-0.067^{* * *}$ & $0.132^{* * *}$ \\
\hline & $(0.004)$ & $(0.004)$ & $(0.008)$ \\
\hline \multirow[t]{2}{*}{ Finance shock } & $0.043^{* * *}$ & $0.018^{* * *}$ & $-0.061^{* * *}$ \\
\hline & $(0.005)$ & $(0.002)$ & $(0.007)$ \\
\hline \multirow[t]{2}{*}{ Customers' ability to pay shock } & $0.019^{* * *}$ & $0.009^{* * *}$ & $-0.029^{* * *}$ \\
\hline & $(0.004)$ & $(0.002)$ & $(0.006)$ \\
\hline \multirow[t]{2}{*}{ Availability of supplies shocks } & $0.017^{* * *}$ & $0.008^{* * *}$ & $-0.025^{* * *}$ \\
\hline & $(0.006)$ & $(0.002)$ & $(0.008)$ \\
\hline$p$-value & 0.000 & & \\
\hline Rho & 0.6 & & \\
\hline Observations & 19,864 & & \\
\hline
\end{tabular}

Standard errors in parentheses. ${ }^{* *} p<0.01,{ }^{* *} p<0.05,{ }^{*} p<0.1$. The estimation of fully observed recursive mixed-process models is obtained using Stata command $\mathrm{cmp}$ written by Roodman (2011). Control variables include structure, ownership and size. Country and sector dummies are also included

25 countries participating in the third WDN survey, the average was $6.9 \%$. The smaller fraction of bonuses and benefits in the total wage bill may reflect the slower economic growth in 2013 relative to the pre-crisis period (2002-2007), but it is also suggestive of an increased role of bonuses in firms' labour cost flexibility, as reflected in a higher share of firms using non-base wages as part of their remuneration mechanisms. This paper explores the behaviour of non-base wage components as a possible adjustment channel available to firms.

We first find that firms facing DNWR are more likely to use bonuses and benefits to reduce labour costs. This finding confirms that in the presence of DNWR during the period 2010-2013, non-base wage components acted as a buffer to overcome DNWR, 
Table 8 Base wage and non-base wage adjustment depending on shock intensity, SUR estimates

\begin{tabular}{|c|c|c|c|}
\hline & (1) & (2) & (3) \\
\hline & Base wages & Base wages & Base wages \\
\hline & Decrease & Unchanged & Increase \\
\hline \multicolumn{4}{|l|}{ Demand } \\
\hline No decrease (reference) & - & - & - \\
\hline \multirow[t]{2}{*}{ Moderate decrease } & $0.043^{* * *}$ & $0.080^{* * *}$ & $-0.123^{* * *}$ \\
\hline & $(0.003)$ & $(0.005)$ & $(0.007)$ \\
\hline \multirow[t]{2}{*}{ Strong transitory decrease } & $0.074^{* * *}$ & $0.116^{* * *}$ & $-0.189^{* * *}$ \\
\hline & $(0.013)$ & $(0.013)$ & $(0.026)$ \\
\hline \multirow[t]{2}{*}{ Strong partly persistent decrease } & $0.070^{* * *}$ & $0.112^{* * *}$ & $-0.182^{* * *}$ \\
\hline & $(0.007)$ & $(0.008)$ & $(0.015)$ \\
\hline \multirow[t]{2}{*}{ Strong long-lasting decrease } & $0.080^{* * *}$ & $0.121^{* * *}$ & $-0.200^{* * *}$ \\
\hline & $(0.007)$ & $(0.007)$ & $(0.013)$ \\
\hline \multirow[t]{2}{*}{ Finance shock } & $0.020^{* * *}$ & $0.033^{* * *}$ & $-0.053^{* * *}$ \\
\hline & $(0.003)$ & $(0.005)$ & $(0.008)$ \\
\hline \multirow[t]{2}{*}{ Customers' ability to pay shock } & $0.007^{* * *}$ & $0.011^{* * *}$ & $-0.018^{* * *}$ \\
\hline & $(0.003)$ & $(0.004)$ & $(0.007)$ \\
\hline \multirow[t]{4}{*}{ Availability of supplies shock } & $0.007^{* *}$ & $0.012^{* *}$ & $-0.019^{* *}$ \\
\hline & $(0.003)$ & $(0.005)$ & $(0.009)$ \\
\hline & Non-base wages & Non-base wages & Non-base wages \\
\hline & Decrease & Unchanged & Increase \\
\hline \multicolumn{4}{|l|}{ Demand } \\
\hline No decrease (reference) & - & - & - \\
\hline \multirow[t]{2}{*}{ Moderate decrease } & $0.089^{* * *}$ & $0.053^{* * *}$ & $-0.142^{* * *}$ \\
\hline & $(0.005)$ & $(0.003)$ & $(0.007)$ \\
\hline \multirow[t]{2}{*}{ Strong transitory decrease } & $0.138^{* * *}$ & $0.056^{* * *}$ & $-0.194^{* * *}$ \\
\hline & $(0.022)$ & $(0.003)$ & $(0.021)$ \\
\hline \multirow[t]{2}{*}{ Strong partly persistent decrease } & $0.159^{* * *}$ & $0.053^{* * *}$ & $-0.212^{* * *}$ \\
\hline & $(0.012)$ & $(0.003)$ & $(0.011)$ \\
\hline \multirow[t]{2}{*}{ Strong long-lasting decrease } & $0.177^{* * *}$ & $0.050^{* * *}$ & $-0.227^{* * *}$ \\
\hline & $(0.011)$ & $(0.003)$ & $(0.010)$ \\
\hline \multirow[t]{2}{*}{ Finance shock } & $0.037^{* * *}$ & $0.017^{* * *}$ & $-0.053^{* * *}$ \\
\hline & $(0.005)$ & $(0.002)$ & $(0.007)$ \\
\hline \multirow[t]{2}{*}{ Customers' ability to pay shock } & $0.020^{* * *}$ & $0.010^{* * *}$ & $-0.030^{* * *}$ \\
\hline & $(0.004)$ & $(0.002)$ & $(0.006)$ \\
\hline \multirow[t]{2}{*}{ Availability of supplies shock } & $0.013^{* *}$ & $0.007^{* *}$ & $-0.020^{* *}$ \\
\hline & $(0.006)$ & $(0.003)$ & $(0.008)$ \\
\hline$p$-value & 0.000 & & \\
\hline Rho & 0.6 & & \\
\hline Observations & 19,634 & & \\
\hline
\end{tabular}

As in Table 7

which prevents firms from cutting base wages. Similar results were found for the period 2002-2007 with data from the first WDN survey. These results have implications for monetary policy. In particular, they suggest that the wage rigidity associated with the overall wage bill may be lower than base wage rigidity alone. Thus, the presence of 
non-base wage components helps achieve overall wage flexibility. In fact, the results indicate that bonuses and benefits played a role as shock absorbers during the period 2010-2013. In particular, demand and credit shocks are both associated with increased use of non-base wage components as a means to adjust costs. Moreover, regression analysis supports the view that the use of bonuses and benefits is not influenced by unionisation; cutting bonuses is thus likely to be a strategy developed outside formal collective bargaining. Larger firms and firms in financial intermediation are among the most likely to adjust non-base wage components.

Then, when comparing adjustment via base wages and non-base wage components, we find that firms which are hit by negative and persistent demand shocks are more likely to reduce wages, with the marginal downward effect on non-base wages being stronger than that on base wages. Other negative shocks (such as finance constraints, customers and supplies) exhibit very consistent negative effects on wages. Non-base wage components react more strongly than base wages to all the types of negative shocks analysed. To sum up, firms use non-base wage components as a buffer to overcome base wage rigidity.

\section{Endnotes}

${ }^{1}$ Bonuses play an important role in personnel economics as a performance incentive (Lazear and Oyer 2007). Bonus payments are usually seen as a way of motivating employees to make more effort in the moral hazard problem on the agents' side (Harris and Raviv 1979; Hölmstrom 1979). The signalling effect of bonuses is also important in giving credible feedback to junior staff and preventing the best workers from looking for outside options (Fuchs 2015).

${ }^{2}$ Our focus is on the role played by wage components. Firms have other margins to make changes in their non-wage labour costs, such as changes in overtime work or shifts policy. These margins are not considered in the paper.

${ }^{3}$ This was a follow-up to the two previous WDN survey waves carried out in 2007 (WDN1, which covered the period 2002-2007) and 2009 (WDN2, which covered the period 2008-2009)

${ }^{4}$ Austria, Belgium, Bulgaria, Croatia, Cyprus, the Czech Republic, Estonia, France, Germany, Greece, Hungary, Ireland, Italy, Latvia, Lithuania, Luxembourg, Malta, the Netherlands, Poland, Portugal, Romania, Slovakia, Slovenia, Spain and the UK.

${ }^{5}$ The statistics presented in descriptive figures and tables are meant to show descriptive statistics about the countries of the sample. Thus, these statistics are not cleaned of composition effects, as country samples may differ by the composition of sectors and firm-size distribution.

${ }^{6}$ The WDN1 survey was the first wave of WDN and was carried out in $17 \mathrm{EU}$ countries between the end of 2007 and the first half of 2008. Conditional on firms paying non-base wages, the figures are $15.6 \%$ in 2007 and 9.7\% in 2013.

${ }^{7}$ The de facto enforcement of wage adjustment restrictions is loose in these countries despite their high EPL scores. These conclusions are confirmed by a large survey of institutional features of wage bargaining (Du Caju et al. 2008).

${ }^{8}$ Of course, some of these freezes could have been due to menu cost or might have been optimal responses to changing conditions. 
${ }^{9}$ In a strict sense, we cannot interpret the results in terms of causality, but rather in terms of correlation, since the measure of DNWR (standard in the literature and used in other papers that do similar exercises) could be endogenous as it refers to the same time period and economic environment.

${ }^{10}$ This may be driven by multicollinearity between the shocks and DNWR itself.

${ }^{11}$ We conducted $z$-tests to compare marginal effects.

\section{Additional files}

Additional file 1: Table S1. Bonuses by country. Table S2. Use of labour cost adjustment channels. Table S3. Relationship between cuts in non-base wage components and base wage rigidity. Table S4. Relationship between non-base wage cuts and wage rigidity - the role of unions. (DOCX $58 \mathrm{~kb}$ )

Abbreviations

DNWR: Downward nominal wage rigidity; ECB: European Central Bank; EPL: Employment protection legislation; SUR: Seemingly unrelated regressions; WDN: Wage Dynamics Network

\section{Acknowledgements}

The work was conducted within the framework of the Wage Dynamics Network coordinated by the European Central Bank. We thank Michal Franta, Eva Hromádková, Juan Francisco Jimeno, Theodora Kosma, Pedro Martins, Daniel Münich, an anonymous referee of the ECB WP series and the participants of the WDN meetings and a seminar at the Czech National Bank for helpful comments. The opinions expressed in this paper are solely those of the authors and do not necessarily reflect the views of their institutions. Responsible editor: Juan F. Jimeno

\section{Funding}

Not applicable.

\section{Availability of data and materials}

Data used should be available upon request to the ECB (https://www.ecb.europa.eu/pub/economic-research/researchnetworks/html/researcher_wdn.en.html).

\section{Competing interests}

The IZA Journal of Labor Policy is committed to the IZA Guiding Principles of Research Integrity. The authors declare that they have observed these principles.

\section{Publisher's Note}

Springer Nature remains neutral with regard to jurisdictional claims in published maps and institutional affiliations.

\section{Author details}

${ }^{1}$ Czech National Bank, Praha, Czech Republic. ${ }^{2}$ Banque de France, Paris, France. ${ }^{3}$ University Paris 1, Paris, France.

${ }^{4}$ Latvijas Banka, Riga, Latvia. ${ }^{5}$ European Central Bank, Frankfurt, Germany. ${ }^{6}$ Deutsche Bundesbank, Frankfurt, Germany.

${ }^{7}$ Banco de Portugal, Lisbon, Portugal. ${ }^{8}$ UECE (Research Unit on Complexity and Economics), Fundação para a Ciência e

a Tecnologia, REM-Research in Economics and Mathematics, Universidade Lusíada de Lisboa, Lisbon, Portugal.

${ }^{9}$ National Bank of Poland, Warsaw, Poland. ${ }^{10}$ SGH Warsaw School of Economics, Warsaw, Poland.

Received: 5 November 2018 Accepted: 25 December 2018

Published online: 31 January 2019

\section{References}

Babecký J, Du Caju P, Kosma T, Lawless M, Messina J, Rõõm T (2012) How do European firms adjust their labour costs when nominal wages are rigid? Labour Econ 19(5):792-801

Bewley TF (1999) Why wages don't fall during a recession. Mass. [u.a.]: Harvard Univ. Press, Cambridge

Cardoso AR, Portugal P (2005) Contractual wages and the wage cushion under different bargaining settings. J Labor Econ 23(4):875-902

Dias DA, Marques CR, Martins F (2013) Wage rigidity and employment adjustment at the firm level: evidence from survey data. Labour Econ 23(C):40-49

Dias DA, Marques CR, Martins F (2015) A replication note on downward nominal and real wage rigidity: survey evidence from European firms. Empir Econ 49(3):1143-1152

Dickens WT, Goette L, Groshen EL, Holden S, Messina J, Schweitzer ME, Turunen J, Ward ME (2007) How wages change: micro evidence from the international wage flexibility project. J Econ Perspect 21(2):195-214

Du Caju P, Gautier E, Momferatou D, Ward-Warmedinger M (2008) Institutional features of wage bargaining in 23 European countries, the US and Japan. In: Working Paper Series 974. European Central Bank

Dwyer J, Leong K (2003) Nominal wage rigidity in Australia. Aust J Lab Econ 6(1):5-24

European Central Bank (2009) Wage dynamics in Europe. Final Report of the Wage Dynamics Network (WDN) http://www. ecb.int/home/html/researcher_wdn.en.html 
Fabiani S, Lamo A, Messina J, Rõõm T (2015) European firm adjustment during times of economic crisis. IZA J Lab Policy 4(1):1-28 Fuchs W (2015) Subjective evaluations: discretionary bonuses and feedback credibility. Am Econ J Microecon 7(1):99-108 Harris M, Raviv A (1979) Optimal incentive contracts with imperfect information. J Econ Theory 20(2):231-259 Hölmstrom B (1979) Moral hazard and observability. Bell J Econ 10(1):74-91

Izquierdo M, Jimeno JF, Kosma T, Lamo A, Millard S, Rõõm T, Viviano E (2017) Labour market adjustment in Europe during the crisis: microeconomic evidence from the wage dynamics network survey. Occasional paper series 192, European Central Bank

Jung S, Schnabel C (2011) Paying more than necessary? The wage cushion in Germany. LABOUR 25(2):182-197

Lazear EP, Oyer P (2007) Personnel economics. National Bureau of Economic Research Working Paper Series No 13480

Lebow DE, Saks RE, Wilson BA (1999) Downward nominal wage rigidity: evidence from the employment cost index. Finance and economics discussion series 1999-31. Board of Governors of the Federal Reserve System (U.S.)

Marotzke P, Anderton R, Bairrao A, Berson C, Tòth P (2017) Asymmetric wage adjustment and employment in European firms. Working Paper Series 2103. European Central Bank

Messina J, Du Caju P, Izquierdo M, Duarte CF, Hansen NL (2010) The incidence of nominal and real wage rigidity: an individual-based sectoral approach. Working Paper Series 1213. European Central Bank

Nickell S, Quintini G (2003) Nominal wage rigidity and the rate of inflation. Econ J 113(490):762-681

Roodman D (2011) Estimating fully observed recursive mixed-process models with cmp. Stat J 11(2):159-206

\section{Submit your manuscript to a SpringerOpen ${ }^{\circ}$} journal and benefit from:

- Convenient online submission

Rigorous peer review

- Open access: articles freely available online

- High visibility within the field

- Retaining the copyright to your article

Submit your next manuscript at $\boldsymbol{\nabla}$ springeropen.com 